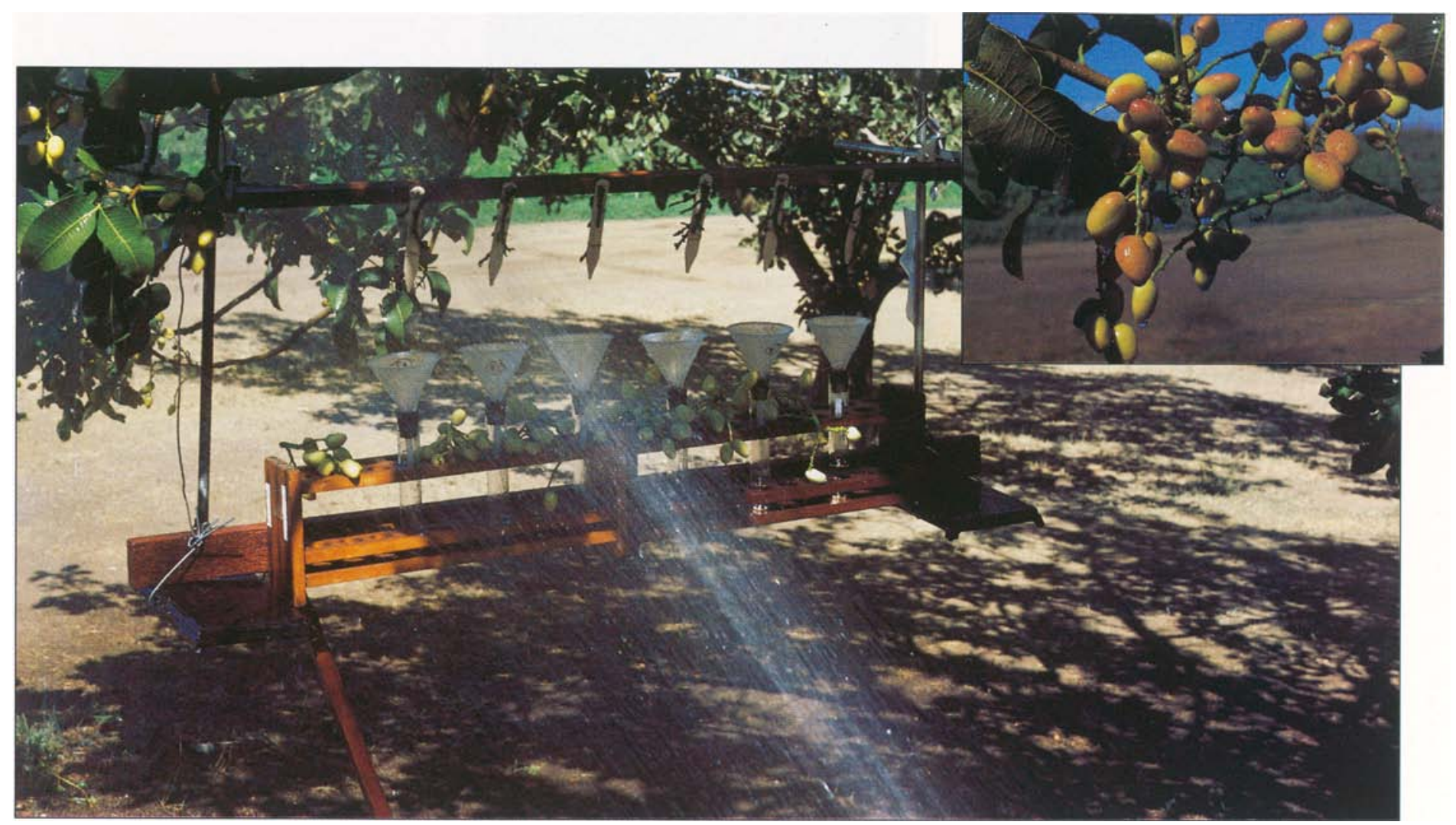

\title{
Adjusting sprinkler angle reduces spread of disease in pistachio
}

Experiment to determine spore release and dispersal of Botryosphaeria dothidea in the Butte County pistachio orchard. Inset, wetted pistachio fruit cluster during irrigation with high-angled sprinklers that will lead to disease development.

Themis J. Michailides

$\square$

David P. Morgan

$\square$

William H. Olson

$\square$

During summer, especially in pistachio orchards irrigated with high-trajectory-angle sprinklers, sprinkler water spreads fungal inocula of Botryosphaeria blight disease to fruit clusters, shoots and leaves. In tests, altering the sprinkler irrigation trajectory angle from $23^{\circ}$ to $12^{\circ}$ prevented release and spread of spore inoculum and significantly reduced the disease in three commercial pistachio orchards in the Sacramento and San Joaquin valleys.

As pistachio acreage in California has increased, fungal diseases have become a major threat, particularly in orchards irrigated by sprinklers. Outbreaks of one disease, Botryosphaeria blight of pista- chio, caused by the fungus Botryosphaeria dothidea, depend solely on availability of spore inoculum of the fungus, spread of the inoculum and conditions favoring infection and disease development.

California's 63,000 acres in pistachio are all irrigated; $5 \%$ are sprinkler-irrigated. In Northern California, however, more than $75 \%$ of pistachio acreage is sprinkler-irrigated. Because rains usually do not occur during late spring and summer, we hypothesized that sprinkler water helps release and spread the pathogen's spores in pistachio orchards during spring, summer and fall. Winter rains can spread $B$. dothidea spores, leading to infected vegetative and reproductive buds in early spring. These then lead to shoot and cluster blight.

We suspected that greater spore inoculum levels, would result in greater disease levels, and we hypothesized that disease could be reduced by altering sprinkler irrigation. This study's objective, therefore, was to determine whether changing the trajectory angle of sprinklers would reduce the release and spread of the pathogen's spores on trees and, consequently, would lower the levels of disease in pistachios. In a previous pistachio orchard study (California Agriculture, November-December 1992) which triggered this research, we were able to reduce this disease by shortening sprinkler irrigations to reduce leaf wetness periods.

\section{Orchard experiments}

Experimental plots. The three pistachio orchards in Butte, Tehama and San Joaquin counties used in this study had moderate-to-high levels of Botryosphaeria panicle and shoot blight. Before this study's initiation (in 1985), all orchards were irrigated by sprinklers of a high $\left(23^{\circ}\right)$ trajectory angle with water 
reaching at least the lower third of the tree canopy. Duration of each irrigation ranged from 24 hours (Butte and Tehama counties) to 48 hours (San Joaquin County).

Spread of spore inoculum in field. Blighted pistachio rachises (the main stems of fruit clusters) represent the most abundant source of spore inoculum for Botryosphaeria blight. In August, just before the fourth sprinkler irrigation of the Butte County orchard, we collected two groups of 1 year-old stems (rachises) showing areas with abundant spore-containing fruiting bodies (pycnidia). One group of rachises (designated "washed" rachises) was collected in areas of the tree canopy (3 to 6 feet high) reached by sprinkler water during the three irrigations before the collection time. The other group ("unwashed" rachises) was collected from areas 7 to 9 feet high on the tree canopy where water could not reach.

Six rachises from each group were attached to a wooden pot label that was then stapled on stakes 4 inches apart from each other. Six 3 -inch plastic funnels, connected with a test tube with a rubber stopper, were placed beneath each rachis group to collect water. Two funnel/test tube constructions, one with "unwashed" and the other with "washed" rachises, were hung 5 feet up on two pistachio trees where water from the grower's sprinklers could reach all the rachises and the fourth irrigation was started. The test tubes were replaced every half hour after the onset of irrigation and spores of $B$. dothidea collected in them were counted in the laboratory with a compound microscope using a hemacytometer.

Six healthy fruit clusters were collected from areas higher than 8 feet in the tree canopy and placed beneath the infected rachises on the rack holding the test tubes and replaced every hour after each test tube replacement. Collected clusters were taken to the laboratory and incubated in plastic containers at $77^{\circ}$ to $80^{\circ} \mathrm{F}$ for 12 days, after which disease incidence was determined. At the end of the field experiment, which lasted 5 hours, the two sets of six rachises were sectioned superficially (to a $1 / 32$ - to $2 / 32$ inch depth) in the laboratory and the pycnidia in them were examined microscopically to determine the presence or absence of spores. This experiment was repeated 1 week later and values were averaged since trends were similar.

Butte County plot. This orchard had been irrigated for about 10 years by portable pipes bearing sprinklers of a hightrajectory angle $\left(23^{\circ}\right)$. A complete ran-

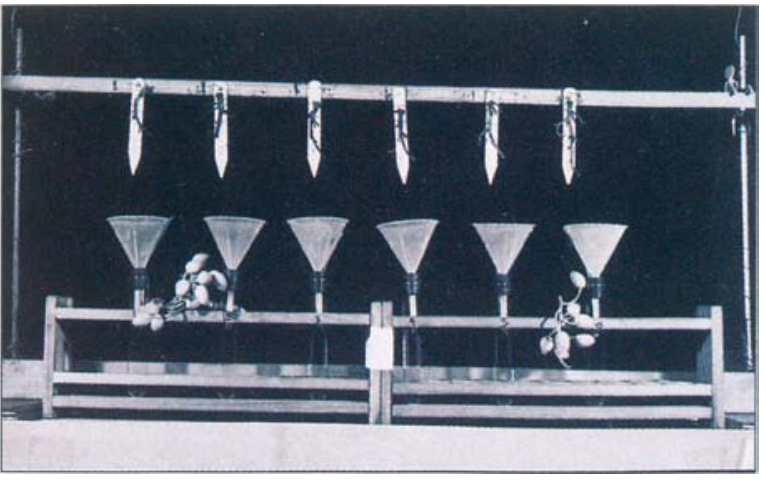

Rachises blighted by Botryosphaeria dothidea were used in a test tube/funnel construction to collect sprinkler irrigation water. Note pistachio rachises tied on pot labels, wooden stake on which labels were stapled, funnels, test tubes, healthy pistachio clusters on the wooden rack holding test tube/funnel system and wire hooks for hanging the test tube/funnel construction on trees in the field.

domized block design was established in late March before beginning irrigations in 3.4 acres of the experimental plot that included four replicated blocks of 84 trees. Half the block (42 trees) was irrigated by high-angled sprinklers; the other half ( 42 trees) was irrigated by low-angled $\left(12^{\circ}\right)$.

Disease data were recorded for 10 randomly preselected and marked shoots. Each shoot had three to seven clusters bearing 20 to 40 fruits at a height of 5 to 6 feet. They were on two trees located in the center of the group of trees irrigated by high- or low-angled sprinklers. Severity of disease was determined May 14 (when small black lesions first appeared), June 4 and July 10. Five disease severity categories were used for fruits: $0=$ healthy fruit without any black lesions, 1 and $2=$ fruit with 5 to 15 lesions and 3 and $4=$ fruit with more than 20 (dense) black lesions. During commercial harvest September 10, fruits from the premarked clusters on the experimental trees were harvested without removing any rachises or leaves from the shoots. Subsamples of 200 fruits per tree were evaluated for incidence of disease, presence of pycnidia and weight of the healthy fruits.

The effects of sprinkler trajectory angle on retained rachises and petioles (leaf stems) were determined by counting hanging rachises and petioles on the premarked shoots and killed shoots $11 / 2$ years later. Representative samples were collected and examined with a dissecting microscope for the presence of $B$. dothidea pycnidia. The white, shiny contents of the pycnidia, representing masses of pycnidiospores of $B$. dothidea, characterize this pathogen.

The effects of altering sprinkler trajectory angle on levels of pycnidiospores and incidence of the fungus on vegetative and flower buds were also determined. Twenty-five vegetative and flower buds were collected at random from four trees in each block irrigated with high- or low-angled sprinklers. Spores of B. dothidea in the sediments of washings from these buds were counted with a microscope. This experiment was done twice, once with buds collected October 1 and once with buds collected October 15. No rain or irrigation occurred during October 1-15.

The incidence of infected buds was determined by collecting 25 buds from each of four trees irrigated with high- or low-angled sprinklers, surface-disinfecting them with a $0.08 \%$ chlorine solution and plating in dishes containing acidified potato-dextrose agar (APDA), five buds per dish. Buds infected by $B$. dothidea were recorded after 5 days' incubation of the dishes at $80 \pm 1^{\circ} \mathrm{F}$. Other sets of buds were washed in 10 milliliter (ml) water and the number of pycnidiospores recovered in the washings was determined by counting them with a hemacy tometer.

In addition, 20 randomly selected current-season shoots for each male and female tree in each block irrigated by high- or low-angled sprinklers were collected October 1 and October 15 and evaluated for the incidence of killed buds and numbers of infected petioles and leaf and bud scars.

Tehama County plot. The experimental plot in the Tehama County pistachio orchard was similar to the one in Butte County, except that each block included 140 trees (10 rows of 14 trees), of which half (10 rows of 7 trees) was irrigated by sprinklers with a high-trajectory angle and the remaining half by sprinklers with a low-trajectory angle. To irrigate all 10 rows, the irrigation pipe had to be moved five times at 24hour intervals. Fruits were harvested September 4 from four trees located in the center of each block, and subsamples of 200 fruits were evaluated for disease as previously described.

San Joaquin County plot. In this orchard, the grower used sprinklers (Rainbird L20 VL) with a 2-mm diameter, off-center nozzle orifice, allowing a change in the trajectory angle from about $23^{\circ}$ to $12^{\circ}$, depending on the nozzle's rotation. The sprinklers were attached to risers from permanent underground pipes. The experimental plot was a complete randomized block design with three replicated blocks. Each block consisted of 60 trees (6 rows of 10 trees) of which 30 trees (6 rows of 5 


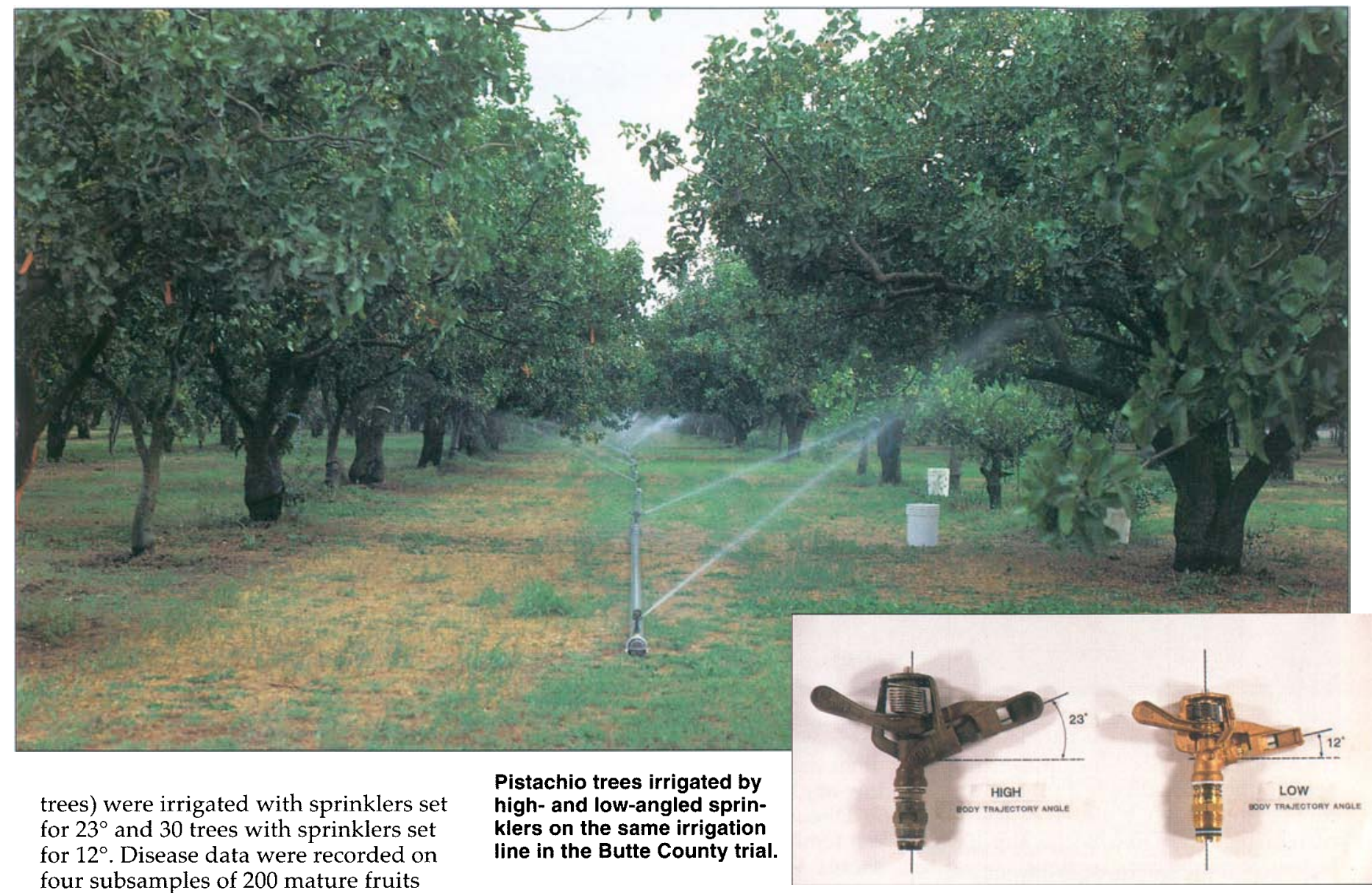
four subsamples of 200 mature fruits and 50 leaves randomly collected from four experimental trees located in the center of each replicated set of trees.

\section{Disease reduction}

Experimental plots. Abundant rachises, petioles and killed shoots were present during spring in all three orchards. Eighty-two to $84 \%$ of the rachises had pycnidia in the orchards in Butte and Tehama counties, respectively, and $70 \%$ of the rachises had pycnidia in the orchard in San Joaquin County. Pycnidiospore germination on APDA ranged from 80 to $94 \%$ in samples collected from all orchards.

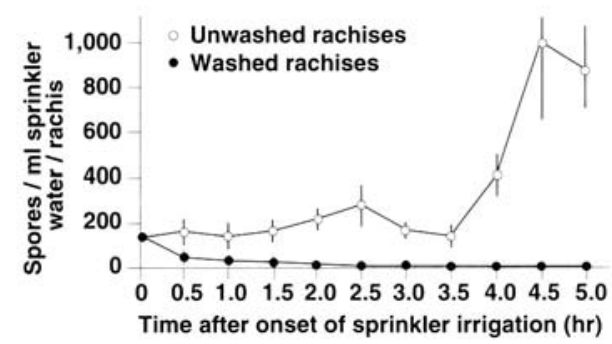

Fig. 1. Numbers of pycnidiospores of Botryosphaeria dothidea collected in blighted rachis runoff water at various times for $\mathbf{5}$ hours after the onset of sprinkler irrigation in the Butte County orchard. Each point represents the average of six replications. Vertical lines at data points represent standard deviations.

Spread of spore inoculum. In this experiment, unwashed rachises were moved so that now they would be "washed" or wetted by sprinkler water. Normally, unwashed rachises would not yield any spores during irrigation since they would not be hit by the water. It took only 5 to 10 minutes after starting the irrigation for spores to be released from washed pycnidia (fig. 1). Unwashed rachises yielded 175 spores $/ \mathrm{ml}$ sprinkler water at the onset of sprinkler irrigation, and this level remained relatively stable for 3.5 hours. Subsequently, spore release increased significantly with the maximum number of spores occurring at 4.5 hours after the onset of irrigation (fig. 1). In contrast, washed rachises yielded only about 180 spores/ $\mathrm{ml}$ water/rachis at the onset of sprinkler irrigation and only a few spores were recovered at the end of the experiment. Maximum temperatures ranged from $90^{\circ}$ to $93^{\circ} \mathrm{F}$, and the minimum temperature was $57^{\circ} \mathrm{F}$, when these experiments took place. All the fruit clusters placed beneath the blighted rachises during the spore release and dispersal experiments had infected nuts after 12 days at $80^{\circ} \mathrm{F}$. Based on microscopic examination of the rachises at the end of the sprinkler experiment, $93 \%$ of the pycnidia in washed
The experimental plot in the Butte County orchard included 84 trees, half of which were irrigated by high-angled $\left(23^{\circ}\right)$ sprinklers (left) and half of which were irrigated by low-angled $\left(12^{\circ}\right)$ sprinklers (right).

(These are Rainbird 29BT, $3.2 \mathrm{~mm}$ nozzle, and Rainbird M2OH, $3.2 \mathrm{~mm}$ nozzle sprinklers, respectively).

rachises and $45 \%$ of the pycnidia in unwashed rachises were empty.

Butte County plot. The number of severely diseased fruit was lower in trees irrigated with low-angled sprinklers than in trees irrigated with highangled sprinklers (table 1). One week after the third sprinkler irrigation, $92 \%$ of the clusters in trees irrigated by the high-angled sprinklers showed infections, compared with $20 \%$ in trees irrigated by low-angled sprinklers. Only $2 \%$ of the clusters at a height of 8 feet (above the water line) were infected; approximately $85 \%$ of them at a height of 4 feet (below the water line) were infected (data not shown).

At commercial harvest, only $31.5 \%$ of the mature fruits on trees irrigated with low-angled sprinklers were infected and $3.6 \%$ bore mature pycnidia. Of the fruits from trees irrigated by sprinklers with a high-trajectory angle, $92.5 \%$ were infected and $13.5 \%$ of them bore pycnidia 


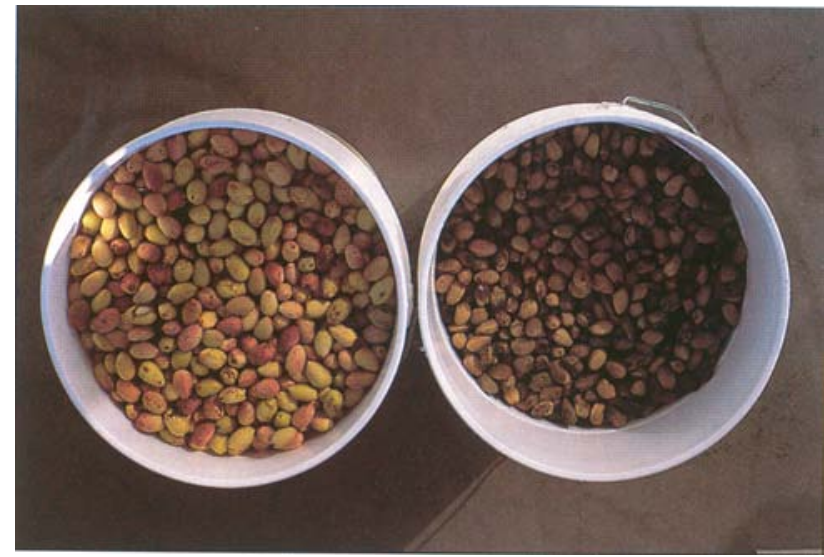

Fruit samples collected from blocks irrigated with low-angled sprinklers (left) and fruit from blocks irrigated with highangled sprinklers (right).

(table 2). The weight of healthy fruit harvested from trees irrigated with lowangled sprinklers was approximately 10 times greater. In addition, irrigating trees with low-angle sprinklers resulted in significantly lower retention of rachises and petioles on the trees and lower frequency of killed shoots than on trees irrigated by sprinklers with a hightrajectory angle (table 2).

Lowering the trajectory angle of sprinklers resulted in fewer spores spread on both male and female buds, lower incidence of bud infection and bud killing, and lower percentages of petiole and bud scar and leaf scar infections (table 3 ).

Tehama County plot. Lowering the trajectory angle of sprinklers in this orchard also resulted in significant disease reduction. Fruit clusters were $69 \%$ blighted in trees irrigated with low-

TABLE 1. Effects of trajectory angle of sprinkler irrigation on disease severity caused by Botryosphaeria dothidea of pistachio fruit clusters in a Butte County orchard, 1985

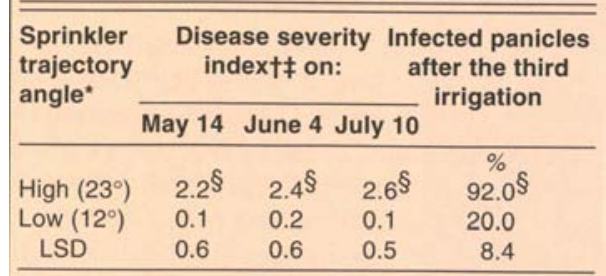

'Four irrigations were applied on May 3-6, May 27 30, July 3-6, and August 3-6.

†Severity index: $0=$ healthy (small black lesions absent); 4 = numerous small black lesions on the epicarp; and 1-3 = intermediate categories with variable numbers of small black lesions but fewer than category 4

$\ddagger$ The same (flagged) panicles were evaluated on all three dates.

$\S$ Significant differences at $\mathrm{P}<0.05$. male trees). trees). angled sprinklers compared with $80 \%$ in trees irrigated with highangled sprinklers. In addition, more than twice as many leaves were infected in trees irrigated with highangled sprinklers.

\section{San Joaquin} County plot. Sprinklers set for a low-trajectory angle resulted in reduced levels of infected fruit, rachises and leaves (table 4). Furthermore, only a few lesions per leaf developed in trees irrigated with sprinklers set for a low-trajectory angle. Over 2.5 times more healthy fruits were harvested from. trees irrigated by sprinklers with nozzles set at $12^{\circ}$ than at $23^{\circ}$ (table 4 ).

\section{Benefits of lower sprinkler angle}

This study's results indicate that Botryosphaeria blight of pistachio can be reduced by lowering the trajectory angle of sprinklers to avoid releasing and spreading spore inoculum. Although irrigation management has been used to control root rot diseases, this, apparently, is the first study to report the manipulation of the sprinkler trajectory angle to control a foliar disease of fruit trees by reducing spore release and dispersal of a pathogen.

Previous studies showed that in spring and summer the sources of inoculum of $B$. dothidea are pycnidia formed in blighted shoots, rachises, petioles, buds, cankers and fruits that hang on trees

TABLE 2. Effects of sprinkler irrigation trajectory angle on Botryosphaeria blight of pistachios and on retention of infected parts in a Butte County orchard, 1985

\begin{tabular}{|c|c|c|c|c|c|c|}
\hline \multirow{2}{*}{$\begin{array}{l}\text { Sprinkler } \\
\text { trajectory } \\
\text { angle* }\end{array}$} & \multirow[b]{2}{*}{$\begin{array}{l}\text { Infected } \\
\text { fruit } †\end{array}$} & \multirow[b]{2}{*}{$\begin{array}{l}\text { Fruit with } \\
\text { pycnidiat }\end{array}$} & \multirow[b]{2}{*}{$\begin{array}{l}\text { Healthy } \\
\text { fruit } \dagger\end{array}$} & \multicolumn{3}{|c|}{ Retention of: $\ddagger$} \\
\hline & & & & Rachises & Petioles & $\begin{array}{l}\text { Killed } \\
\text { shoots }\end{array}$ \\
\hline & \multicolumn{2}{|c|}{ 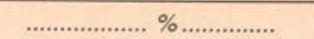 } & $g$ & ............ & .... no. ........ & $\ldots . . .$. \\
\hline High $\left(23^{\circ}\right)$ & $92.5 \S$ & $13.5 \S$ & $42.7 \S$ & $32.3 \S$ & $9.7 \S$ & $5.2 \S$ \\
\hline $\operatorname{Low}\left(12^{\circ}\right)$ & 31.5 & 3.6 & 405.9 & 16.3 & 0.5 & 2.3 \\
\hline LSD & 8.4 & 2.3 & 46.6 & 8.5 & 3.7 & 1.8 \\
\hline
\end{tabular}

*Irrigations on May 3-6, May 27-30, July 3-6 and August 3-6.

†Values of six 200-fruit samples harvested on September 10.

¥Abnormal retention of rachises and petioles on the tree and frequency of killed shoots were determined 1.5 years after the start of the experiment.

§Significant differences at $\mathrm{P}<0.05$

TABLE 3. Effects of sprinkler irrigation trajectory angle on the numbers of pycnidiospores of Botryosphaeria dothidea on pistachio buds and disease incidence in buds, petioles, and bud and leaf scars in a Butte County orchard, 1985

\begin{tabular}{|c|c|c|c|c|c|c|}
\hline \multirow{2}{*}{$\begin{array}{l}\text { Sprinkler } \\
\text { trajectory } \\
\text { angle }\end{array}$} & \multirow{2}{*}{$\begin{array}{c}\text { Spores } \\
\text { per } \\
\text { bud }\end{array}$} & \multirow{2}{*}{$\begin{array}{c}\text { Incidence of } \\
\text { B. dothidea } \\
\text { in buds* }\end{array}$} & \multirow[b]{2}{*}{$\begin{array}{l}\text { Dead } \\
\text { buds }\end{array}$} & \multicolumn{3}{|c|}{ Total infections per 20 twigs $\dagger$} \\
\hline & & & & Petioles & $\begin{array}{l}\text { Leaf } \\
\text { scars }\end{array}$ & $\begin{array}{l}\text { Bud } \\
\text { scars }\end{array}$ \\
\hline & & \multicolumn{2}{|c|}{ 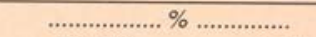 } & \multicolumn{3}{|c|}{ 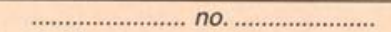 } \\
\hline High $\left(23^{\circ}\right)$ & $113,158 \ddagger$ & $70.8^{*} \S$ & $8.3 \S$ & $3.9 \S$ & $1.3 \S$ & 0.6 \\
\hline Low $\left(12^{\circ}\right)$ & 16,22 & 38.6 & 0.4 & 0.1 & 0.1 & 0.0 \\
\hline LSD & & 14.6 & 3.3 & 1.0 & 0.5 & 0.6 \\
\hline
\end{tabular}

"Average of 4 four-tree replications, each including 50 randomly collected buds (25 each from male and fe-

†Average of four replications, each of 40 randomly selected shoots ( 20 from male and 20 from female

‡For male and female trees, respectively.

$\S$ Significant difference at $\mathrm{P}<0.05$.

TABLE 4. Effects of sprinkler trajectory angle on Botryosphaeria panicle and shoot blight of pistachio in a San Joaquin County orchard, 1989

\begin{tabular}{|c|c|c|c|c|c|}
\hline $\begin{array}{l}\text { Sprinkler } \\
\text { trajectory } \\
\text { angle* }\end{array}$ & $\begin{array}{c}\text { Healthy } \\
\text { fruit }\end{array}$ & $\begin{array}{c}\text { Infected } \\
\text { fruit } †\end{array}$ & $\begin{array}{l}\text { Infected } \\
\text { rachises }\end{array}$ & $\begin{array}{l}\text { Blighted } \\
\text { rachises }\end{array}$ & $\begin{array}{l}\text { Infected } \\
\text { leaves } \neq\end{array}$ \\
\hline & $g$ & 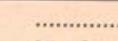 & $\ldots \ldots \ldots$ & & \\
\hline High $\left(\simeq 23^{\circ}\right)$ & $212 \S$ & $65.5 \S$ & $29.0 \S$ & 1.5 & $93.8 \S$ \\
\hline $\operatorname{Low}\left(\simeq 12^{\circ}\right)$ & 561 & 6.2 & 2.1 & 0.0 & 65.2 \\
\hline LSD & 49 & 4.9 & 8.1 & 2.1 & 9.1 \\
\hline
\end{tabular}

"High = upper-side setting of nozzle orifice; low = lower-side setting of nozzle orifice.

†Values of twelve 200-fruit samples harvested September 25.

¥Values of twelve 50-leaf samples.

$\S$ Significantly different at $\mathrm{P}<0.05$. 


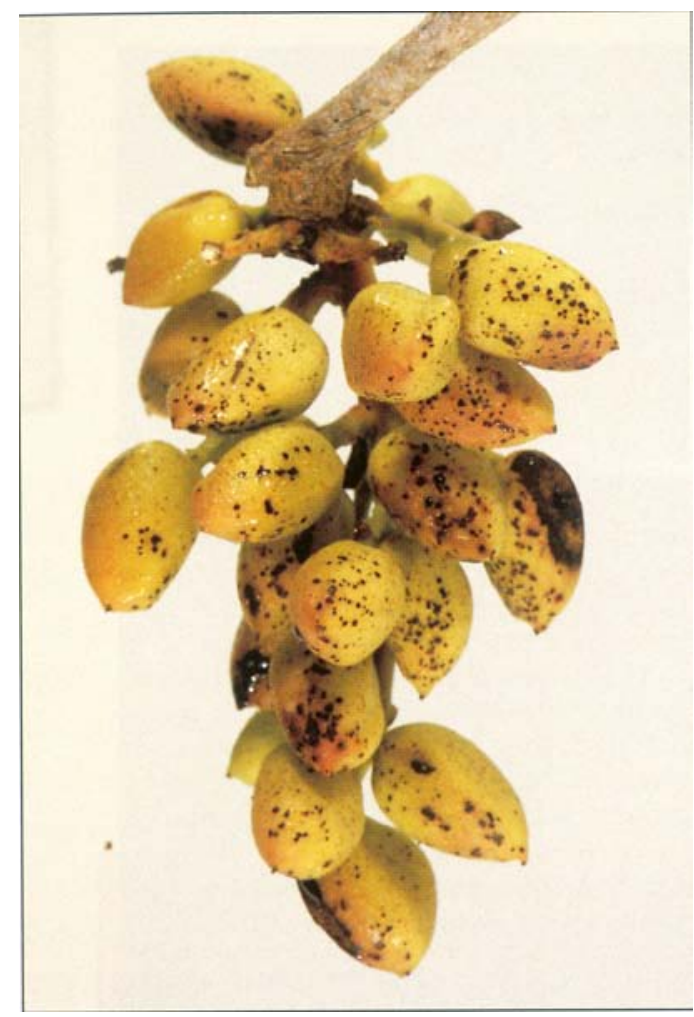

Symptoms (small black lesions on epicarp) of Botryosphaeria disease on pistachio immature fruit.

from previous year(s). In laboratory studies we showed that fewer pycnidia released spores on sprinkler-washed rachises than unwashed rachises because pycnidia in washed rachises were depleted of spores when spores were released with each irrigation. Also, 2-yearold rachises found firmly attached and retained on trees still had several pycnidia full of viable spores, indicating that blighted rachises can supply fungal inoculum for at least 2 years.

Because rains did not occur during the growing season (June to August), when these experiments took place, dispersal depended entirely on water from sprinkler irrigation. In fact, immediately after irrigation was initiated, sprinklerwater washed pycnidiospores from the rachises onto the trees in the field and the first symptoms appeared after 2 weeks. The more the rachises were sprinkled, the more the pycnidiospores were washed from the pycnidia.

It is believed that rainwater (mainly in fall, winter and/or early spring) can also effectively remove and spread pycnidiospores from any plant part bearing pycnidia. In the Butte County orchard, a light rain September 9 wetted the rachises, causing spores to exude directly on the trees from pycnidia in rachises observed with a hand lens September 10. Any following rain will effectively disperse the already exuded spores. For example, within 5 minutes

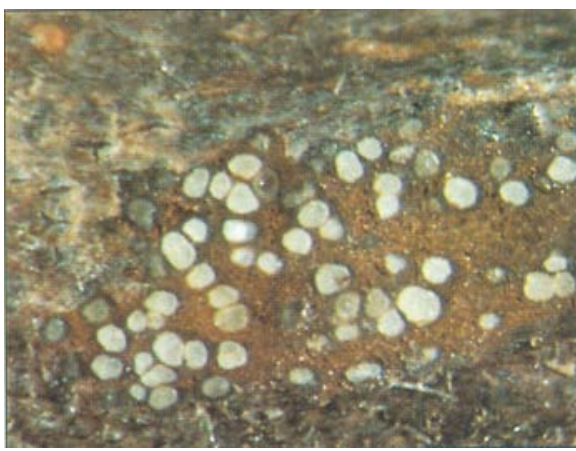

A longitudinal section along a pistachio rachis reveals the pycnidia (white dots) of Botryosphaeria dothidea.

after starting sprinkler irrigation, approximately 25,000 pycnidiospores per $\mathrm{ml}$ of water per rachis were collected from rachises with exuding pycnidia, as had been shown in our laboratory experiments. However, because most crop development occurs in summer, the effect of irrigation is more important than rains in late fall, winter or early spring.

Water from sprinklers with a lowtrajectory angle reaches only small areas of the tree canopy, resulting in limited spore release and dispersal and lower chances for infection of fruits, leaves, rachises, buds or shoots. In contrast, water ejected from high-angled sprinklers reaches much of the lower part of the tree canopy, washes spores from rachises hanging there and creates ideal conditions for disease development. Spores of $B$. dothidea germinate in water after only 1.5 hours with about 90 to $95 \%$ germinating after 5 hours. Since each irrigation in these orchards lasted 24 to 48 hours, wetness periods were sufficient for spore germination and infection of fruits and leaves. In a previous study, we showed that at least 6 hours of continuous wetness were necessary for considerable levels of infection of pistachio leaves after inoculation (California Agriculture, November-December 1992).

Lowering the trajectory angle of sprinklers resulted in reducing sources of the spore inoculum (fewer infected rachises, petioles and killed shoots and buds with lower levels of fruit that bore pycnidia). This means fewer infections during late fall in the current year and fewer infections in future year(s). Improved disease control by lowering the trajectory angle of sprinklers almost certainly results in dispersal of fewer spores and less favorable conditions for infection (sites were not wetted). Less spore dispersal on trees irrigated with low-angled sprinklers is indicated by the significantly smaller numbers of pycnidiospores of $B$. dothidea recovered from buds collected from these trees (table 3). Less favorable conditions for establishing infection among the bud scales is indicated by fewer infected buds (table 3 ).

Multiple infections of leaves defoliated both male and female trees from the end of August to the beginning of September in orchards in Butte and Tehama counties. Disease severity was greater on leaves of female trees than on leaves of male trees. Under the same conditions, female trees may be under greater demands for nutrients, as they bear fruiting clusters, and nutritional stresses cannot be avoided. Nutritional or water stresses have been shown to be associated with greater susceptibility of other trees to $B$. dothidea.

Control of Botryosphaeria blight of pistachio by using benomyl (Benlate 50 WP) or Kocide 101 (the only fungicides registered for pistachio) is unsatisfactory. Control of the disease was greatly facilitated by altering sprinkler trajectory angle. At least four growers replaced high-angled sprinklers with low; as a result of this change, the grower in Butte County experienced a $40 \%$ increase over the previous year's yield, although the year when these studies took place was a low production year.

A $46 \%$ increase in yield was reported in the San Joaquin County orchard after the trajectory angle of the sprinklers was reduced. For example, in 1988, a high production year for pistachio, the grower had the sprinkler nozzles set for high-trajectory angle to achieve a longer trajectory distance. This arrangement, however, created an outbreak of the disease and only 12,000 pounds net weight of pistachios were harvested; in 1989, a low production year, sprinklers were set at a $12^{\circ}$ angle and about 23,000 pounds were harvested from the same orchard.

Because of increasing concerns about the excessive use of pesticides in agriculture, nonpesticidal methods for controlling disease, such as those developed in this study, should be regarded as environmentally safe and valuable disease controls for California's pistachio industry.

T. J. Michailides is Associate Plant Pathologist and D. P. Morgan is Staff Research Associate III, Department of Plant Pathology, UC Davis, located at the Kearney Agricultural Center, Parlier; W. H. Olson is Farm Advisor, Butte County, and J. A. Grant is Farm Advisor, San Joaquin County.

The authors thank F. $\&$ M. Montgomery (Almond Orchards, Durham, California), J. Bradford (Ballards Orchards Corporation, Vina, California), and R. Schrum (pistachio grower) for their cooperation and permission to manipulate sprinkler trajectory angles in their orchards. This research was supported by funds from the California Pistachio Commission. 